\title{
Multipliers in an Island Economy: The Case of the Azores
}

\author{
EDUARDO A. HADDAD \\ Vasco Silva
}

Alexandre A. Porsse

TOMAz DENTINHo 
DEPARTMENT OF ECONOMICS, FEA-USP

WORKING PAPER № 2012-21

\title{
Multipliers in an Island Economy: The Case of the Azores
}

\author{
Eduardo A. Haddad (ehadadd@usp.br) \\ Vasco Silva (vascofaria@uac.pt) \\ Alexandre A. Porsse (porsse@gmail.com) \\ Tomaz Dentinho (tomazdentinho@uac.pt)
}

\begin{abstract}
:
In this paper we present the interisland input-output system for the Azores. It includes the economy of the nine islands of the archipelago, considering 25 different economic activities. The paper also analyses the impacts of the main drivers of the islands economy incorporating both spillover and feedback effects in the evaluation of the multipliers: i) dairy and beef exports; ii) external public support; and iii) tourism, both from the rest of the country and from abroad. It is shown that: i) the economic structure of the islands is quite different from each other; ii) the specific economic base of the islands are also different and, as expected, the biggest islands not only capture an important part of the impact of external pushes done in smaller islands but also they constitute important drivers of smaller islands.
\end{abstract}

Keywords: Input-Output, Islands, Regional Development, Azores

JEL Codes: R11, R15 


\title{
Multipliers in an Island Economy: The Case of the Azores
}

\author{
Eduardo Haddad $^{1}$, Vasco Silva $^{2}$, Alexandre Porsse ${ }^{3}$ and Tomaz Dentinho ${ }^{4}$
}

\begin{abstract}
In this paper we present the interisland input-output system for the Azores. It includes the economy of the nine islands of the archipelago, considering 25 different economic activities. The paper also analyses the impacts of the main drivers of the islands economy incorporating both spillover and feedback effects in the evaluation of the multipliers: i) dairy and beef exports; ii) external public support; and iii) tourism, both from the rest of the country and from abroad. It is shown that: i) the economic structure of the islands is quite different from each other; ii) the specific economic base of the islands are also different and, as expected, the biggest islands not only capture an important part of the impact of external pushes done in smaller islands but also they constitute important drivers of smaller islands.
\end{abstract}

\section{Introduction}

Insularity results from the combination of smallness, associated with limiting factors, and remoteness, linked to the distant location of its final demand. Smallness can be viewed as land insufficiency, lack of specialized labour or shortage of venture capital, reduced markets and scale diseconomies, also in standardized public services. Insularity is then a technological specificity, where some resources are available but bounded, that shapes the social structures and geographical identities. The combination of smallness with remoteness explains the occurrence of export monocultures because the whole island stays within the same Von Thünen ring influenced by local capabilities and by distant external markets. Being so, small changes in market conditions or in external accessibilities can produce great modifications in the export base generating economic cycles with strong effects in the islands livelihoods. Finally the overwhelming pressure for monoculture creates rents over the scarce economic resources whose spatial allocation depends on the control over transport value chains and on the structure of ownership. Being so, the regional coefficients of the input-output (IO) matrix of each island can be quite different from the one observed in another island or in the mainland,

\footnotetext{
${ }^{1}$ Universidade de São Paulo, São Paulo, Brasil; CNPq scholar

${ }^{2}$ Universidade dos Açores, Angra do Heroísmo, Portugal

${ }^{3}$ Universidade Federal do Paraná, Curitiba, Brasil

${ }^{4}$ Universidade dos Açores, Angra do Heroísmo, Portugal
} 
either because there is some limiting factor or because the income generated migrates elsewhere.

The challenge of this paper is to analyze the effects of insularity in the economy looking into the IO multiplier effects in archipelagic economies for the case of the nine islands of the Azores. Input-Output modelling - linked to the Economic Tables of François Quesnay (1758) and with the idea of general equilibrium proposed in the book Elements d'Économie Politique Pure written by Léon Walras in 1874 - was first developed by Leontieff (1951), Leontieff et al. (1953) and Chenery and Clark (1959), and since then there has been many applications and developments, reviewed in the book of InputOutput Analysis (Miller and Blair, 2009).

The Azores are nine small islands (Figure 1) spread across $600 \mathrm{~km}$ - East-West - in the North Atlantic, half way between Portugal and Newfound Land. The islands are wet and green, warm but windy, with average temperatures between $16^{\circ} \mathrm{C}$ in January and $22^{\circ} \mathrm{C}$ in August and with rainfall ranging between 762 and $1525 \mathrm{~mm}$. Less than a quarter of a million Portuguese people live in the islands, quite different in size and population and with very different distances from each other. The economy of the Azores, like any other place, rests on its human, social and productive capital moulded by four main natural features: good conditions for agriculture, strategic location, unique beauty, and a large Exclusive Economic Zone. The use of these potentialities, driven by outside markets and by outwards strategic equilibriums, evolved through time determining the performance of the economy, its crises and recoveries (Dentinho, 1995).

Figure 1. The Azores Archipelago

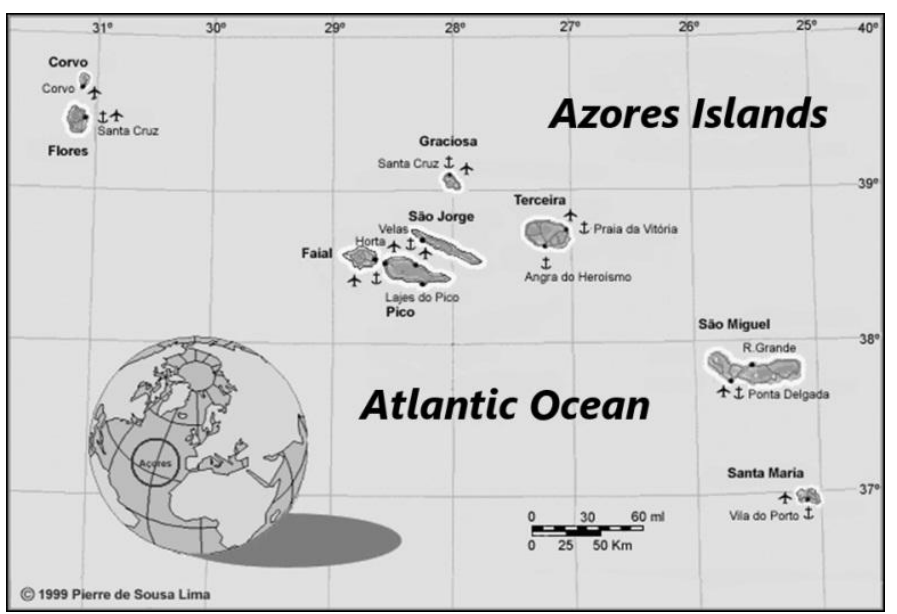


The economic base of the Azores has evolved throughout time. Based on the agricultural capabilities, the islands exported wheat since the sixteen century until the middle of the twenty century, ink plants in the seventeen and eighteen century, oranges in the nineteen century, and dairy products since the 1960s. Grounded on its strategic location, the Azores islands were essential for sail navigation from the sixteen to the nineteen century for the return trips to Europe, from America, from Africa and from Asia through the Cape of Good Hope. Steam engines and railways created a backlash on that relative centrality, but transcontinental flights find some utility in the islands for civil and military purposes after the Second World War (Monjardino, 1990). The large Economic Exclusive Zone is gaining its importance, and the unilateral public transfers from mainland Portugal and from the European Union, that took place in the last decades, are the counterpart of securing some ownership over these ocean resources. The unique beauty of the landscape is also providing some benefits from the increasing touristic flows, although never reaching the importance of the other natural capital. Finally, the islands also export human resources that, for some time, generate unilateral transfers to the households and to the economy; the South of Brazil was populated by Azoreans in the eighteen century and the Azorean communities in Bermuda, New England, California and Toronto function nowadays as "additional" islands of the Azorean Archipelago.

Looking at the IO matrix of 2001 (SREA, 2006), the actual inflows to the economy of the islands come from dairy and beef exports, from fisheries, from external public transfers, that represent $30 \%$ of the regional public administration budget, from tourism, and from other exports. The issue dealt in this paper is to assess what the spatial multiplier effects of (changes in) those sectors are; furthermore when most of those changes are strongly influenced by public decisions - through agricultural, fishery and transportation policies, and through direct allocation of public spending among the islands.

In 2004 the Centro de Investigação Regional e Urbana (CIRIUS) from the Instituto Superior de Economia e Gestão (ISEG) created an IO table for the Azores with 16 sectors for the year of 1998. Alves et al. (2004) tried to use statistical data on maritime transportation to estimate the flows between the Azores and mainland Portugal. Ramos 
and Sargento (2003) disaggregated the IO matrix for 1995 for seven Portuguese regions, including the Azores. The Serviço Regional de Estatística dos Açores (SREA) published in 2006 an enlarged table of employment for the Azores in 2001, with 25 sectors. Ferreira (2006) built up the regional IO table for the Azores with 45 sectors, using information on the employment and production according to the method described in Almond (2000). Then, based on disaggregation methods (Flegg, 1994) and biproportional techniques (Jackson, 2004), in the particular form of crossed entropy methods (Robinson, 2001), Ferreira was able to disaggregate that table for the Azores into three regional IO tables: São Miguel, Terceira and the Rest of the Azores, nevertheless without looking into the interisland flows.

The aim now is to generate an interregional IO system, including all the islands of the Azores, through the estimation of the inter-industry and interisland economic flows and their association with the existing structure of the transport and communication system. There has been many approaches to merge IO models with transportation network analysis (Boyce, 2002) along the models reviewed by (Batten et al. 1986) and following the initial work by Wilson (1970) on interregional commodity flows. Other contributors include Polenske (1980), Hewings (1985) and, more recently, Haddad et al. (2011).

Summing up: first, the application of IO models to archipelagos cannot be done assuming that the productive system is totally explained by the technological coefficients of the whole archipelago without considering the decisive role of transportation networks and bounded resources; second, it is advisable to create spatially disaggregate models for archipelagos because policies and their effects are necessarily spatially disaggregated; and, finally, recent techniques and improved data allow the development of operational models suitable to support decision makers. In this context, the aim of this paper is to analyze the effects of insularity in the economy looking at the IO multiplier effects of the economic base in archipelagic economies for the case of the nine islands of the Azores. More specifically, the aim is to provide insights and support for the analysis of the impacts of the main basic activities in the archipelagos, namely agricultural and dairy, fishery, external public transfers, and tourism. 
To address these issues, the study is divided in four distinct parts beyond the introduction. Section 2 describes the methodological framework to be used in the analysis, describing the interisland IO model for the archipelago. Section 3 briefly discusses the main aspects related to the estimation of the interisland IO system, which serves as the basis for the application that is carried out in section 4 to analyze differential multiplier effects of the main components of the economic bases of the island economies. Final remarks follow.

\section{Methodology}

The conventional input-output model is given by the system of matrix equations:

$x=A x+f$

$x=(I-A)^{-1} f=B f$

where $x$ and $f$ are the vectors of gross output and final demand, respectively; $A$ consists of input coefficients $a_{i j}$ defined as the amount of product $i$ required per unit of product $j$ (in monetary terms), for $i, j=1, \ldots, \mathrm{n}$; and $B$ is known as the Leontief inverse.

Let us consider systems (1) and (2) in an interregional context, with $R$ different regions, so that:

$x=\left[\begin{array}{c}x^{1} \\ \vdots \\ x^{R}\end{array}\right] ; A=\left[\begin{array}{ccc}A^{11} & \cdots & A^{1 R} \\ \vdots & \ddots & \vdots \\ A^{R 1} & \cdots & A^{R R}\end{array}\right] ; f=\left[\begin{array}{c}f^{1} \\ \vdots \\ f^{R}\end{array}\right] ;$ and $B=\left[\begin{array}{ccc}B^{11} & \cdots & B^{1 R} \\ \vdots & \ddots & \vdots \\ B^{R 1} & \cdots & B^{R R}\end{array}\right]$

and

$$
\begin{aligned}
& x^{1}=B^{11} f^{1}+\cdots+B^{1 R} f^{R} \\
& x^{R}=B^{R 1} f^{1}+\cdots+B^{R R} f^{R}
\end{aligned}
$$


Focusing on the elements directly related to the economic base, let us also consider the different components of $f$, which include tourists expenditures in the islands, both from the rest of Portugal, $t$, and from abroad, $i$, exports of goods and services to Mainland Portugal, $p$, and to foreign markets, $s$, government expenditures financed by external unilateral transfers ${ }^{5}, c$, and other final demand expenditures, $e$.

$t=\left[\begin{array}{c}t^{1} \\ \vdots \\ t^{R}\end{array}\right] ; i=\left[\begin{array}{c}i^{1} \\ \vdots \\ i^{R}\end{array}\right] ; p=\left[\begin{array}{c}p^{1} \\ \vdots \\ p^{R}\end{array}\right] ; e=\left[\begin{array}{c}s^{1} \\ \vdots \\ S^{R}\end{array}\right] c=\left[\begin{array}{c}c^{1} \\ \vdots \\ c^{R}\end{array}\right] ; e=\left[\begin{array}{c}e^{1} \\ \vdots \\ e^{R}\end{array}\right]$

Thus, we can re-write (4) as:

$$
\begin{gathered}
x^{1}=B^{11}\left(t^{1}+i^{1}+p^{1}+s^{1}+c^{1}+e^{1}\right)+\cdots+B^{1 R}\left(t^{R}+i^{R}+p^{R}+s^{R}+c^{R}+e^{R}\right) \\
\vdots \\
x^{R}=B^{R 1}\left(t^{1}+i^{1}+p^{1}+s^{1}+c^{1}+e^{1}\right)+\cdots+B^{R R}\left(t^{R}+i^{R}+p^{R}+s^{R}+c^{R}+e^{R}\right)
\end{gathered}
$$

With (5), we can then compute the contribution of the components of the economic base to the islands output. It is clear from (5) that an island output depends, among others, on direct money injections in the island itself and, depending on the degree of interregional integration among the islands in the Azores, also on injections in other islands.

\section{The Interisland Input-Output Model for the Azores}

This section provides an overview of the process through which the Interisland InputOutput Model for the Azores (IIOMA) was constructed, based on the available data. The departure point was the Input-Output Table for the Azores (2001) which includes 25 sectors.

\footnotetext{
${ }^{5}$ Regarding public transfers, there would be a need to include the discrimination of public expenditures supported by external unilateral transfers to the islands, both from the rest of Portugal and from abroad. Even though this information can be obtained from the regional accounts, which provide the monetary values of supports coming mostly from Mainland Portugal and from the European Union, we did not make this distinction. The reason is that we have assumed the same structure of public expenditures in the islands regardless the source of financing. Thus, the $\mathrm{p}$ vector was estimated as a share of government expenditures.
} 
The first step was to disaggregate the Azorean data into the 9 islands, using information provided by the Serviço Regional de Estatística dos Açores (SREA) on employment by sector and by island, average wages per island and average wages per sector in the whole of Portugal, the balance of supply and demand per sector in each one of the islands, and on the distances between the islands corrected for the cost of embark and disembark. $^{6}$

Table 1 presents the shares of each of the islands in the various components of the final demand in the archipelago. We have highlighted the exports of agricultural and dairy products (agro), as well as the exports fishery products. A general result is the spatial concentration of aggregate final demand in São Miguel $(53,4 \%)$ and Terceira $(22,7 \%)$ which is very likely influenced by the distribution of economic activity and population of the islands.

Table 1. Shares of the Islands in the Components of Final Demand in the Azores

\begin{tabular}{|c|c|c|c|c|c|c|c|c|c|c|c|}
\hline & Santa Maria & São Miguel & Terceira & Graciosa & São Jorge & Pico & Faial & Flores & Corvo & Total & $\begin{array}{c}\text { Structure of } \\
\text { Final Demand }\end{array}$ \\
\hline Investment & $1.8 \%$ & $54.3 \%$ & $21.4 \%$ & $1.9 \%$ & $3.2 \%$ & $7.6 \%$ & $7.7 \%$ & $1.9 \%$ & $0.2 \%$ & $100.0 \%$ & $21.9 \%$ \\
\hline Consumption & $2.3 \%$ & $53.5 \%$ & $23.5 \%$ & $1.8 \%$ & $4.0 \%$ & $6.0 \%$ & $7.0 \%$ & $1.7 \%$ & $0.2 \%$ & $100.0 \%$ & $33.7 \%$ \\
\hline Exports Agro Portugal & $1.5 \%$ & $54.7 \%$ & $20.3 \%$ & $2.9 \%$ & $4.6 \%$ & $6.0 \%$ & $8.3 \%$ & $1.6 \%$ & $0.1 \%$ & $100.0 \%$ & $8.0 \%$ \\
\hline Exports Agro Other & $1.3 \%$ & $49.4 \%$ & $17.8 \%$ & $5.7 \%$ & $2.7 \%$ & $3.6 \%$ & $18.5 \%$ & $1.1 \%$ & $0.0 \%$ & $100.0 \%$ & $0.1 \%$ \\
\hline Exports Fishery Portugal & $2.2 \%$ & $46.4 \%$ & $11.6 \%$ & $1.0 \%$ & $4.6 \%$ & $23.8 \%$ & $9.6 \%$ & $0.6 \%$ & $0.1 \%$ & $100.0 \%$ & $0.8 \%$ \\
\hline Exports Fishery Other & $2.1 \%$ & $45.0 \%$ & $10.5 \%$ & $0.7 \%$ & $4.9 \%$ & $26.1 \%$ & $10.2 \%$ & $0.4 \%$ & $0.1 \%$ & $100.0 \%$ & $0.4 \%$ \\
\hline Exports Other Portugal & $8.5 \%$ & $67.2 \%$ & $9.9 \%$ & $0.5 \%$ & $2.4 \%$ & $1.7 \%$ & $7.9 \%$ & $1.8 \%$ & $0.0 \%$ & $100.0 \%$ & $4.7 \%$ \\
\hline Exports Other Other & $8.9 \%$ & $64.0 \%$ & $12.0 \%$ & $0.7 \%$ & $1.5 \%$ & $2.3 \%$ & $8.5 \%$ & $2.0 \%$ & $0.1 \%$ & $100.0 \%$ & $1.4 \%$ \\
\hline Tourism Portugal & $2.3 \%$ & $49.6 \%$ & $20.1 \%$ & $1.9 \%$ & $2.6 \%$ & $6.7 \%$ & $14.4 \%$ & $2.4 \%$ & $0.0 \%$ & $100.0 \%$ & $1.1 \%$ \\
\hline Tourism Other & $1.7 \%$ & $65.0 \%$ & $12.4 \%$ & $0.7 \%$ & $1.9 \%$ & $6.2 \%$ & $10.1 \%$ & $2.0 \%$ & $0.0 \%$ & $100.0 \%$ & $1.5 \%$ \\
\hline Government & $2.3 \%$ & $48.3 \%$ & $28.3 \%$ & $1.9 \%$ & $3.8 \%$ & $5.2 \%$ & $7.8 \%$ & $1.9 \%$ & $0.3 \%$ & $100.0 \%$ & $23.5 \%$ \\
\hline Stocks & $1.5 \%$ & $52.1 \%$ & $20.6 \%$ & $2.8 \%$ & $8.3 \%$ & $9.2 \%$ & $3.3 \%$ & $1.6 \%$ & $0.5 \%$ & $100.0 \%$ & $2.9 \%$ \\
\hline Final Demand & $2.5 \%$ & $53.4 \%$ & $22.7 \%$ & $1.9 \%$ & $3.8 \%$ & $6.2 \%$ & $7.6 \%$ & $1.8 \%$ & $0.2 \%$ & $100.0 \%$ & $100.0 \%$ \\
\hline
\end{tabular}

The economic base of the archipelago is just $25.1 \%$ of the final demand ${ }^{7}$ and mainly constituted by (Table 2) dairy and beef exports (32.5\%), unilateral transfers $(28.1 \%)$, other exports - mainly from transport, financial services and other agricultural products $(24.4 \%)$, tourism $(10.4 \%)$, and fishery (4.6\%). Concerning exports, $98.4 \%$ of dairy and beef, $64.7 \%$ of fishery, $42.5 \%$ of tourism, and $76.3 \%$ of other exports go to Mainland Portugal.

There are specificities in the economic base of the islands: dairy and beef is more relevant for Graciosa and São Jorge; unilateral transfers are more important for Corvo and Terceira due respectively to the smallness of Corvo and the existence of an

\footnotetext{
${ }^{6}$ Details on the methodology can be found in Haddad et al. (2011).

${ }^{7}$ This is equivalent to $43.1 \%$ of the archipelago GRP.
} 
American military base in Terceira; fishery plays an important relative role in Faial and Pico; tourism is relatively more relevant for São Miguel, Pico, Faial and Flores; and other exports are more significant for the more diversified island of São Miguel and for the special case of Santa Maria, where the Air Control of the North Atlantic is located.

Table 2. Structure of the Economic Base of the Islands

\begin{tabular}{lcccccccccc}
\hline & Santa Maria & São Miguel & Terceira & Graciosa & São Jorge & Pico & Faial & Flores & Corvo & Total \\
\cline { 2 - 9 } Exports Agro Portugal & $13.8 \%$ & $31.4 \%$ & $33.7 \%$ & $51.1 \%$ & $41.5 \%$ & $33.9 \%$ & $30.8 \%$ & $29.6 \%$ & $21.8 \%$ & $32.0 \%$ \\
Exports Agro Other & $0.2 \%$ & $0.4 \%$ & $0.5 \%$ & $1.6 \%$ & $0.4 \%$ & $0.3 \%$ & $1.1 \%$ & $0.3 \%$ & $0.1 \%$ & $0.5 \%$ \\
Exports Fishery Portugal & $1.8 \%$ & $2.5 \%$ & $1.8 \%$ & $1.7 \%$ & $3.9 \%$ & $12.6 \%$ & $3.4 \%$ & $1.0 \%$ & $3.1 \%$ & $3.0 \%$ \\
Exports Fishery Other & $1.0 \%$ & $1.3 \%$ & $0.9 \%$ & $0.6 \%$ & $2.3 \%$ & $7.5 \%$ & $1.9 \%$ & $0.4 \%$ & $1.2 \%$ & $1.6 \%$ \\
Exports Other Portugal & $44.6 \%$ & $22.5 \%$ & $9.6 \%$ & $5.5 \%$ & $12.8 \%$ & $5.4 \%$ & $17.1 \%$ & $18.9 \%$ & $4.9 \%$ & $18.6 \%$ \\
Exports Other Other & $14.5 \%$ & $6.6 \%$ & $3.6 \%$ & $2.2 \%$ & $2.5 \%$ & $2.3 \%$ & $5.7 \%$ & $6.5 \%$ & $2.6 \%$ & $5.8 \%$ \\
Tourism Portugal & $2.8 \%$ & $3.9 \%$ & $4.6 \%$ & $4.7 \%$ & $3.3 \%$ & $5.2 \%$ & $7.4 \%$ & $6.0 \%$ & $1.5 \%$ & $4.4 \%$ \\
Tourism Other & $2.8 \%$ & $7.0 \%$ & $3.9 \%$ & $2.3 \%$ & $3.2 \%$ & $6.5 \%$ & $7.1 \%$ & $6.9 \%$ & $1.0 \%$ & $6.0 \%$ \\
Government (dependent)* & $18.5 \%$ & $24.3 \%$ & $41.4 \%$ & $30.4 \%$ & $30.2 \%$ & $26.0 \%$ & $25.6 \%$ & $30.4 \%$ & $64.0 \%$ & $28.1 \%$ \\
Economic Base & $100.0 \%$ & $100.0 \%$ & $100.0 \%$ & $100.0 \%$ & $100.0 \%$ & $100.0 \%$ & $100.0 \%$ & $100.0 \%$ & $100.0 \%$ & $100.0 \%$ \\
\hline
\end{tabular}

* Government expenditures financed by external transfers

The second step was to disaggregate the Azorean IO Matrix into the 9 islands of the Archipelago. Following Chenery (1956) and Moses (1955), we assumed, for each island, the same commodity mixes for different users (producers, investors, households and government) as those presented in the regional IO tables for the Azores. For sectoral cost structures, value added generation may be different across regions. Trade matrices for each commodity were used to disaggregate the origin of each commodity in order to capture the structure of the spatial interaction in the Azorean economy. In other words, for a given user, say agriculture sector, the mix of intermediate inputs will be the same in terms of its composition, but it will differ from the sources of supply.

The strategy for estimating the 25 trade matrices (one for each commodity in the system) included the following steps:

1. We have initially estimated total supply (output) of each commodity by island, excluding exports to other countries. Thus, for each island, we obtained information for the total sales of each commodity for the domestic markets.

$\operatorname{Supply}(c, s)=$ supply for the domestic markets of commodity $c$ by island $s$

2. Following that, we have estimated total demand, in each island, for the aforementioned 25 commodities. To do that, we have assumed the respective users' 
structure of demand followed the Azorean pattern. With the island levels of sectoral production, investment demand, household demand and government demand, we have estimated the initial values of total demand for each commodity in each island, from which the demand for imported commodities were deducted. The resulting estimates, which represent the island total demand for Azorean goods, were then adjusted so that, for each commodity, demand across islands equals supply across islands.

$\operatorname{Demand}(c, d)=$ demand of commodity $c$ by island $d$

3. With the information for Supply(c,s) and $\operatorname{Demand}(c, d)$, the next step was to estimate, for each commodity $c$, matrices of trade $(9 \times 9)$ representing the transactions of each commodity among Azorean islands. We have fully relied on the methodology described in Dixon e Rimmer (2004), based on the so called Horridge formulae. The procedure considered the following steps:

a) For the diagonal cells, equation (6) was implemented, while for the off-diagonal elements, equation (7) is the relevant one:

$\operatorname{SHIN}(c, d, d)=\operatorname{Min}\left\{\frac{\operatorname{Supply}(c, d)}{\operatorname{Demand}(c, d)}, 1\right\} * F(c)$

$\operatorname{SHIN}(c, o, d)=\left\{\frac{1}{\operatorname{Dist}(o, d)} \cdot \frac{\operatorname{Supply}(c, o)}{\sum_{k=1}^{22} \operatorname{Supply}(c, k)}\right\} *\left\{\frac{1-\operatorname{SHIN}(c, d, d)}{\sum_{j=1, j \neq d}^{22}\left[\frac{1}{\operatorname{Dist}(j, d)} \cdot \frac{\operatorname{Suply}(c, j)}{\sum_{k=1}^{22} \operatorname{Suply}(c, k)}\right]}\right\}$

where $c$ refers to a given commodity, and $o$ and $d$ represent, respectively, origin and destination regions.

The variable Dist $(o, d)$ refers to the distance between two trading islands. The factor $F(c)$ gives the extent of tradability of a given commodity. For the non-tradables (usually services), typically assumed to be locally provided goods, we have used the value of 0.9 for $F(c)$, adopting a usual assumption, while for tradables, the value of $F(c)$ was set to 
0.5 . It can be shown that the column sums in the resulting matrices add to one. What these matrices show are the supply-adjusted shares of each island in the specific commodity demand by each island of destination.

Once these share coefficients are calculated, we then distribute the demand of commodity $c$ by region $d(\operatorname{Demand}(c, d))$ across the corresponding columns of the SHIN matrices. Once we adopt this procedure, we have to further adjust the matrices to make sure that supply and demand balance. This is done through a RAS procedure.

Tables 3 and Table 4 show the resulting structure of trade among the Azores islands, (aggregated across commodities) respectively excluding and including the interisland flows for consumption and investment goods. We have also included island demand for imported commodities (last row), estimated considering the structure of demand according to the Azorean pattern. It is clear that the sources of supply for the Archipelago are Mainland Portugal, São Miguel and Terceira - regarding intermediary flows -, and São Miguel, Mainland Portugal and Terceira - for flows of intermediary and final goods and services.

In the next section, we continue to evaluate the general structure of the IO Matrix for the Archipelago of the Azores focusing on the multiplier effects of the economic base.

Table 3. Structure of Interisland Trade Flows of Intermediary Goods and Services

\begin{tabular}{|c|c|c|c|c|c|c|c|c|c|c|}
\hline & Santa Maria & São Miguel & Terceira & Graciosa & São Jorge & Pico & Faial & Flores & Corvo & Total \\
\hline Santa Maria & $25 \%$ & $2 \%$ & $0 \%$ & $1 \%$ & $1 \%$ & $1 \%$ & $1 \%$ & $0 \%$ & $1 \%$ & $1 \%$ \\
\hline São Miguel & $13 \%$ & $41 \%$ & $17 \%$ & $20 \%$ & $19 \%$ & $17 \%$ & $16 \%$ & $13 \%$ & $24 \%$ & $31 \%$ \\
\hline Terceira & $2 \%$ & $8 \%$ & $29 \%$ & $9 \%$ & $7 \%$ & $7 \%$ & $7 \%$ & $4 \%$ & $9 \%$ & $13 \%$ \\
\hline Graciosa & $0 \%$ & $0 \%$ & $0 \%$ & $31 \%$ & $0 \%$ & $0 \%$ & $1 \%$ & $0 \%$ & $0 \%$ & $1 \%$ \\
\hline São Jorge & $0 \%$ & $1 \%$ & $1 \%$ & $2 \%$ & $29 \%$ & $2 \%$ & $2 \%$ & $1 \%$ & $2 \%$ & $2 \%$ \\
\hline Pico & $0 \%$ & $2 \%$ & $1 \%$ & $2 \%$ & $3 \%$ & $28 \%$ & $3 \%$ & $2 \%$ & $3 \%$ & $3 \%$ \\
\hline Faial & $0 \%$ & $1 \%$ & $1 \%$ & $2 \%$ & $2 \%$ & $3 \%$ & $34 \%$ & $2 \%$ & $3 \%$ & $3 \%$ \\
\hline Flores & $0 \%$ & $0 \%$ & $0 \%$ & $0 \%$ & $0 \%$ & $0 \%$ & $0 \%$ & $32 \%$ & $3 \%$ & $1 \%$ \\
\hline Corvo & $0 \%$ & $0 \%$ & $0 \%$ & $0 \%$ & $0 \%$ & $0 \%$ & $0 \%$ & $0 \%$ & $37 \%$ & $0 \%$ \\
\hline Imports & $60 \%$ & $45 \%$ & $49 \%$ & $33 \%$ & $39 \%$ & $42 \%$ & $37 \%$ & $45 \%$ & $18 \%$ & $45 \%$ \\
\hline Total & $100 \%$ & $100 \%$ & $98 \%$ & $100 \%$ & $100 \%$ & $100 \%$ & $101 \%$ & $99 \%$ & $100 \%$ & $100 \%$ \\
\hline
\end{tabular}


Table 4: Structure of Interisland Trade Flows of Intermediary and Final Goods and Services

\begin{tabular}{|c|c|c|c|c|c|c|c|c|c|c|}
\hline & Santa Maria & São Miguel & Terceira & Graciosa & São Jorge & Pico & Faial & Flores & Corvo & Total \\
\hline Santa Maria & $32 \%$ & $2 \%$ & $1 \%$ & $1 \%$ & $1 \%$ & $1 \%$ & $1 \%$ & $1 \%$ & $1 \%$ & $3 \%$ \\
\hline São Miguel & $20 \%$ & $54 \%$ & $23 \%$ & $24 \%$ & $22 \%$ & $21 \%$ & $20 \%$ & $17 \%$ & $29 \%$ & $39 \%$ \\
\hline Terceira & $3 \%$ & $10 \%$ & $42 \%$ & $12 \%$ & $9 \%$ & $9 \%$ & $9 \%$ & $6 \%$ & $12 \%$ & $17 \%$ \\
\hline Graciosa & $0 \%$ & $0 \%$ & $0 \%$ & $38 \%$ & $1 \%$ & $1 \%$ & $1 \%$ & $0 \%$ & $1 \%$ & $1 \%$ \\
\hline São Jorge & $0 \%$ & $1 \%$ & $1 \%$ & $2 \%$ & $38 \%$ & $2 \%$ & $2 \%$ & $1 \%$ & $2 \%$ & $3 \%$ \\
\hline Pico & $0 \%$ & $2 \%$ & $2 \%$ & $3 \%$ & $3 \%$ & $38 \%$ & $3 \%$ & $2 \%$ & $3 \%$ & $4 \%$ \\
\hline Faial & $1 \%$ & $1 \%$ & $1 \%$ & $3 \%$ & $3 \%$ & $4 \%$ & $43 \%$ & $2 \%$ & $4 \%$ & $4 \%$ \\
\hline Flores & $0 \%$ & $0 \%$ & $0 \%$ & $1 \%$ & $0 \%$ & $1 \%$ & $1 \%$ & $45 \%$ & $4 \%$ & $1 \%$ \\
\hline Corvo & $0 \%$ & $0 \%$ & $0 \%$ & $0 \%$ & $0 \%$ & $0 \%$ & $0 \%$ & $0 \%$ & $36 \%$ & $0 \%$ \\
\hline Imports & $44 \%$ & $28 \%$ & $31 \%$ & $18 \%$ & $23 \%$ & $24 \%$ & $21 \%$ & $26 \%$ & $8 \%$ & $28 \%$ \\
\hline Total & $100 \%$ & $98 \%$ & $101 \%$ & $102 \%$ & $100 \%$ & $101 \%$ & $101 \%$ & $100 \%$ & $100 \%$ & $100 \%$ \\
\hline
\end{tabular}

\section{Interisland Multiplier Effects of the Economic Base}

This section presents the results of the economic base multiplier effects derived from the IIOMA. We first look at the aggregate output multipliers for the main components of the archipelago's economic base (Table 5), identifying the main drivers of the Azorean economy.

We then consider, for each island, the ratio of the total effects generated in the local economy by the whole Azorean economic base to the island economic base itself. This indicator gives the extent to which the island is capable of internalizing a bigger share of the multiplier benefits of the archipelago's economic base. Whenever this indicator is greater than the average multiplier for the whole archipelago, the island is shown to have a greater capability of benefiting from the structural interdependence in the system (Table 6).

Finally we perform a spatial decomposition of the archipelago's output by taking into account not only the multiplier structure embedded in the IIOAM, but also the structure of the economic-base components of final demand in the 9 islands (Sonis et al., 1996). According to equation (5), the Azorean output multiplier was decomposed, and the contributions of the (aggregated) components of the economic bases from different islands were calculated. Differently from the previous exercise, which considers the combined effect of the archipelago's economic base, we consider here the standard definition of the output multiplier for each island economic base separately. The results are presented in Table 7. 
Table 5. Economic-Base Total Output Multipliers in the Azores, by Component

\begin{tabular}{ll}
\hline Exports Agro Portugal & 1,96 \\
Exports Agro Other & 2,12 \\
Exports Fishery Portugal & 1,61 \\
Exports Fishery Other & 1,66 \\
Exports Other Portugal & 1,57 \\
Exports Other Other & 1,48 \\
Tourism Portugal & 1,83 \\
Tourism Other & 1,83 \\
Government (dependent) & 1,31 \\
Economic Base & $\mathbf{1 , 6 5}$ \\
\hline
\end{tabular}

Looking at the main drivers of the Azorean economy it is quite clear that, although agricultural-related (agro) exports and external public transfers (government-dependent) are the main components of the economic base of the islands (Table 2), their multiplier effects are quite different. The higher multipliers are associated with agro exports to Portugal and to other countries, highlighting the importance of the cluster associated with dairy exports. This suggests a major challenge to expand agro exports to other countries since they have an output multiplier of 2,12 (Table 5) although representing only $0,5 \%$ of the economic base (Table 2). It is also revealing that the multiplier effect of external transfers is just 1,31 indicating that the leakages associated with most of public spending, driven by self-financed government spending or by external transfers, is very high. This somehow reinforces the idea that the combination of smallness with remoteness explains the occurrence of export monocultures in the islands (see section 1) and it should be through the improvement of the competitiveness of those monocultures that it is possible to promote growth.

Table 6. Island-Economic-Base Output Multipliers in the Azores

\begin{tabular}{ll}
\hline Santa Maria & 1,78 \\
São Miguel & 1,65 \\
Terceira & 1,69 \\
Graciosa & 1,57 \\
São Jorge & 1,83 \\
Pico & 1,68 \\
Faial & 1,49 \\
Flores & 1,56 \\
Corvo & 1,53 \\
Total & $\mathbf{1 , 6 5}$ \\
\hline
\end{tabular}


The results of Table 6 can be explained by the smallness and remoteness of the different islands that compose the Azorean Archipelago, as well as the spatial hierarchy within the Azores. As expected, the economic base of São Miguel, representing more than half of the islands' economy, presents a multiplier effect of its economic base very close to the multiplier effect of the economic base of the archipelago. With exception of Santa Maria, very much closed and linked to São Miguel, all the other smaller and more remote islands - Graciosa, Faial, Flores and Corvo - have stronger leakages associated with their economic base multiplier effects when compared to the average economic base multiplier effect of the Azores. Furthermore, the islands that present relatively lower leakages than the average are relatively larger and are also closer to each other Terceira, Pico and São Jorge.

Table 7. Spatial Decomposition of the Multipliers of the Islands' Economic Bases

\begin{tabular}{|c|c|c|c|c|c|c|c|c|c|c|}
\hline & \multicolumn{10}{|c|}{ Origin of the economic base } \\
\hline & Santa Maria & São Miguel & Terceira & Graciosa & São Jorge & Pico & Faial & Flores & Corvo & Total \\
\hline Santa Maria & $84,1 \%$ & $1,4 \%$ & $0,5 \%$ & $0,5 \%$ & $0,4 \%$ & $0,5 \%$ & $0,6 \%$ & $0,6 \%$ & $0,4 \%$ & $3,8 \%$ \\
\hline São Miguel & $12,1 \%$ & $87,6 \%$ & $15,4 \%$ & $15,4 \%$ & $13,8 \%$ & $14,3 \%$ & $13,3 \%$ & $10,5 \%$ & $10,7 \%$ & $55,5 \%$ \\
\hline Terceira & $2,2 \%$ & $6,4 \%$ & $79,8 \%$ & $6,2 \%$ & $5,1 \%$ & $5,4 \%$ & $5,3 \%$ & $3,8 \%$ & $3,9 \%$ & $19,7 \%$ \\
\hline Graciosa & $0,1 \%$ & $0,4 \%$ & $0,3 \%$ & $72,2 \%$ & $0,4 \%$ & $0,5 \%$ & $0,5 \%$ & $0,3 \%$ & $0,2 \%$ & $1,7 \%$ \\
\hline São Jorge & $0,4 \%$ & $1,3 \%$ & $1,2 \%$ & $1,8 \%$ & $76,2 \%$ & $1,9 \%$ & $1,7 \%$ & $1,1 \%$ & $1,1 \%$ & $3,9 \%$ \\
\hline Pico & $0,5 \%$ & $1,6 \%$ & $1,4 \%$ & $2,0 \%$ & $2,1 \%$ & $74,8 \%$ & $2,6 \%$ & $1,3 \%$ & $1,3 \%$ & $5,7 \%$ \\
\hline Faial & $0,4 \%$ & $1,1 \%$ & $1,1 \%$ & $1,6 \%$ & $1,7 \%$ & $2,3 \%$ & $75,5 \%$ & $1,2 \%$ & $1,3 \%$ & $7,7 \%$ \\
\hline Flores & $0,1 \%$ & $0,3 \%$ & $0,3 \%$ & $0,4 \%$ & $0,3 \%$ & $0,4 \%$ & $0,4 \%$ & $80,9 \%$ & $1,2 \%$ & $1,7 \%$ \\
\hline Corvo & $0,0 \%$ & $0,0 \%$ & $0,0 \%$ & $0,0 \%$ & $0,0 \%$ & $0,0 \%$ & $0,0 \%$ & $0,1 \%$ & $80,1 \%$ & $0,1 \%$ \\
\hline Multiplier & 1,57 & 1,67 & 1,61 & 1,72 & 1,63 & 1,65 & 1,69 & 1,59 & 1,40 & 1,65 \\
\hline Intra-regional & 1,32 & 1,46 & 1,28 & 1,24 & 1,24 & 1,23 & 1,28 & 1,29 & 1,12 & - \\
\hline Interregional & 0,25 & 0,21 & 0,32 & 0,48 & 0,39 & 0,41 & 0,41 & 0,30 & 0,28 & - \\
\hline
\end{tabular}

Table 7 decomposes the multiplier effect of the economic base of each island on the island itself and on the different islands. There are many issues that arise. First, looking at the information on the magnitudes of the multipliers, it is clear that islands like Graciosa, more specialized in agro exports (Table 2) - that has higher multiplier effects (Table 5) - have higher multiplier effects associated with their economic base than islands, such as the case of Corvo, more dependent on external public transfers (Table 2). Second, and as expected, the bigger island, São Miguel, internalizes a major share of the multiplier effect, presenting the highest intra-regional multiplier. Nevertheless, showing the protection created by distance, more remote islands, like Santa Maria, Flores and Corvo, are also able to integrate more than $80 \%$ of the multiplier effect. Third, islands of the central group that are closer to each other (Terceira, Graciosa, São Jorge, Pico and Faial) share the multiplier effects with the neighbor islands. Fourth, the 
bigger island of São Miguel and also, to some extent, the second biggest island (Terceira) are able to capture some of the multiplier effects of the economic base of the other islands revealing the centralities of the Archipelago. Finally, there are clear signs of spatial spillovers between Faial and Pico made possible by the short distance $(5 \mathrm{Km})$ and interconnection (frequent ferryboat) between those two islands.

\section{Concluding Remarks}

The argument of this paper is that economic models for archipelagic regions should be disaggregate into the different islands in order to understand the functioning of the economy and to evaluate policy impacts more accurately. With the data available and using IO disaggregation methodology, we show that: i) the economic structure of the islands is quite different from each other; ii) the specific economic base of the islands are also different and, as expected, the biggest islands not only capture an important part of the impact of external pushes done in smaller islands but also they constitute important drivers of smaller islands.

\section{References}

Almond, C. (2000). Product-to-product tables via product-technology with no negative flows. Economic Systems Research, 12 (1):27-43.

Alves, Martins et al. (2004) - Sistemas de Matrizes Regionais de Input-Output para a Região Autónoma dos Açores 1998. Relatório Metodológico e Resultados. Subsecretário Regional do Planeamento e Assuntos Europeus. Direcção Regional de Estudos e Planeamento, Abril de 2004.

Batten, D.F. and Boyce, D.E. (1986) Spatial Interaction, Transportation and Interregional Commodity Flow Models. In P.Nijkamp, ed. Handbook of Regional and Urban Economics, Volume I. Amsterdam, North-Holland, pp.357406.

Boyce, D. (2002) Combined Model of Interregional Commodity Flows on a Transportation Network. In Trade, Networks and Hierachies, Modelling Regional and Interregional Economies. Edited by Hewings, J.D.; Sonis, M. and Boyce, D. Springer 
Chenery, H. B. (1956). Interregional and International Input-Output Analysis. In: T. Barna (ed.), The Structure Interdependence of the Economy, New York: Wiley, pp. 341-356.

Chenery and Clark (1959) Interindustry economics. Wiley. New York.

Dentinho, TP (1995) - Information and Communication Technologies and Regional Development. The case of the Azores dairy value chain. $\mathrm{PhD}$ Thesis. University of Newcastle - upon - Tyne. United Kingdom.

Dixon, P. B. and Rimmer, M. T. (2004). Disaggregation of Results from a Detailed General Equilibrium Model of the US to the State Level. General Working Paper No. 145, Centre of Policy Studies, April.

Ferreira, P (2006) - Projecção Espacial da Tabela Input-Output dos Açores. Tese de Mestrado. Departamento de Economia e Gestão. Universidade dos Açores.

Flegg, A. T. (1994) On the appropriate use of location quotients in generating regional input-output tables. Regional Studies, 29(6): 547-561

Haddad, EH, Samaniego JMG, Porsse AA, Jimenez, DAO, Moreno WSO, Souza, LGA (2011) - Interregional Input-Output System for Equador, 2007: Methodology and Results. TD Nereus 03-2011, São Paulo.

Hewings,G.J.D.(1985): Regional Input-Output Analysis. Beverly Hills, Sage Publications Inc.

Jackson, R. (2004) Alternative input-output matrix updating formulations. Economic Systems Research, 16 (2):135-148.

Leontieff, W.W. (1951) The structure of the American economy, 1919-1939. Oxford University Press, New York.

Leontieff W.W. et al. (1953): Studies in the Structure of the American Economy. Oxford University Press, New York.

Miller, R. e Blair, P. (2009), Input-Output Analysis - Foundations and Extensions, 2. Edition, Cambridge University Press. Cambridge, UK.

Monjardino, A (1989) - Os Açores no contexto do Atlântico. Relações transatlânticas no limiar do século XXI, Universidade dos Açores, pg. 205-212.

Moses, L. N. (1955). The Stability of Interregional Trading Patterns and Input-Output Analysis, American Economic Review, vol. XLV, no. 5, pp. 803-832.

Polenske, K.R. (1980) The U.S. Multiregional Input-Output Accounts and Model. Lexington Books (D.C. Heath and Co.), Lexington, Mass. 
Ramos, P and Sargento, A (2003) Estimating trade flows between Portuguese regions using an input-output approach. 43th Congress of the European Regional Science Association, Jywaskyla (Finland), August 27-30, 2003.

Robinson, S. \& Cattaneo, M.E.- S. (2001) Updating and estimating a social accounting matrix using cross entropy methods. Economic Systems Research, 13(1):47-64.

SREA (2006) - Matrizes Intersectoriais dos Açores, 2001. Serviço Regional de Estatística dos Açores.

Wilson, A.G. (1970) Interregional Commodity Flows: Entropy Maximizing Procedures. Geographical Analysis, 2, 255-282. 


\section{Annex 1. Distances in the Azores}

\section{Direct Distance}

\begin{tabular}{|l|c|c|c|c|c|c|c|c|c|}
\hline & $\begin{array}{c}\text { Santa } \\
\text { Maria }\end{array}$ & $\begin{array}{c}\text { São } \\
\text { Miguel }\end{array}$ & Terceira & Graciosa & São Jorge & Pico & Faial & Flores & Corvo \\
\hline Santa Maria & 0 & 100 & 265 & 345 & 330 & 340 & 360 & 575 & 585 \\
\hline São Miguel & 100 & 0 & 170 & 250 & 250 & 260 & 280 & 500 & 510 \\
\hline Terceira & 265 & 170 & 0 & 95 & 120 & 125 & 145 & 360 & 370 \\
\hline Graciosa & 345 & 250 & 95 & 0 & 75 & 80 & 85 & 270 & 280 \\
\hline São Jorge & 330 & 250 & 120 & 75 & 0 & 20 & 40 & 250 & 260 \\
\hline Pico & 340 & 260 & 125 & 80 & 20 & 0 & 25 & 240 & 250 \\
\hline Faial & 360 & 280 & 145 & 85 & 40 & 25 & 0 & 235 & 245 \\
\hline Flores & 575 & 500 & 360 & 270 & 250 & 240 & 235 & 0 & 15 \\
\hline Corvo & 585 & 510 & 370 & 280 & 260 & 250 & 245 & 15 & 0 \\
\hline
\end{tabular}

\section{Frequency of transport}

\begin{tabular}{|l|c|c|c|c|c|c|c|c|c|}
\hline & $\begin{array}{c}\text { Santa } \\
\text { Maria }\end{array}$ & $\begin{array}{c}\text { São } \\
\text { Miguel }\end{array}$ & Terceira & Graciosa & São Jorge & Pico & Faial & Flores & Corvo \\
\hline Santa Maria & 0 & 2 & 2 & 2 & 2 & 2 & 2 & 2 & 3 \\
\hline São Miguel & 2 & 0 & 1 & 2 & 2 & 2 & 1 & 2 & 3 \\
\hline Terceira & 2 & 1 & 0 & 2 & 2 & 2 & 1 & 2 & 3 \\
\hline Graciosa & 2 & 2 & 2 & 0 & 2 & 2 & 2 & 2 & 3 \\
\hline São Jorge & 2 & 2 & 2 & 2 & 0 & 2 & 2 & 2 \\
\hline Pico & 2 & 2 & 2 & 2 & 2 & 0 & 1 & 2 & 3 \\
\hline Faial & 1 & 1 & 1 & 2 & 2 & 1 & 0 & 2 & 3 \\
\hline Flores & 2 & 1 & 1 & 2 & 2 & 2 & 2 & 0 & 1 \\
\hline Corvo & 3 & 2 & 2 & 3 & 3 & 3 & 3 & 1 & 0 \\
\hline
\end{tabular}

Formula (Distance of the model $=150+0,5 *$ Direct Distance $+10 *$ Frequency)

\begin{tabular}{|l|c|c|c|c|c|c|c|c|c|}
\hline & $\begin{array}{c}\text { Santa } \\
\text { Maria }\end{array}$ & $\begin{array}{c}\text { São } \\
\text { Miguel }\end{array}$ & Terceira & Graciosa & São Jorge & Pico & Faial & Flores & Corvo \\
\hline Santa Maria & 150 & 220 & 302,5 & 342,5 & 335 & 340 & 350 & 457,5 & 472,5 \\
\hline São Miguel & 220 & 150 & 245 & 295 & 295 & 300 & 300 & 420 & 435 \\
\hline Terceira & 302,5 & 245 & 150 & 217,5 & 230 & 232,5 & 232,5 & 350 & 365 \\
\hline Graciosa & 342,5 & 295 & 217,5 & 150 & 207,5 & 210 & 212,5 & 305 & 320 \\
\hline São Jorge & 335 & 295 & 230 & 207,5 & 150 & 180 & 190 & 295 & 310 \\
\hline Pico & 340 & 300 & 232,5 & 210 & 180 & 150 & 172,5 & 290 & 305 \\
\hline Faial & 340 & 300 & 232,5 & 212,5 & 190 & 172,5 & 150 & 287,5 & 302,5 \\
\hline Flores & 457,5 & 410 & 340 & 305 & 295 & 290 & 287,5 & 150 & 167,5 \\
\hline Corvo & 472,5 & 425 & 355 & 320 & 310 & 305 & 302,5 & 167,5 & 150 \\
\hline
\end{tabular}

